\title{
Assessment of Renewable Energy in India
}

\author{
Rijul Dhingra, Abhinav Jain, Abhishek Pandey, and Srishti Mahajan
}

\begin{abstract}
Most of the power generation in India is carried out by conventional energy sources, coal and mineral oil-based power plants which contribute heavily to greenhouse gases emission. This focuses the solution of the energy crisis on judicious utilization of abundant renewable energy resources. This paper reviews the renewable energy scenario of India. It begins by describing the importance of renewable energy and its advantages over fossil fuels. It gives an overview of the renewable energies in India while evaluating the current status and the deployment of each of these technologies to date in India. It also reviews the multi-criteria assessment of different renewable energy and draws out vital conclusions. It is based on the secondary information collected from various mass media including internet, various reports and other International Institutions.
\end{abstract}

Index Terms-Conventional energy sources, greenhouse gases, renewable energy.

\section{INTRODUCTION}

In this competitive world, every country wants to be in the league of developed countries by rapid growth and employment generation. The pernicious effect and ecological disequilibrium caused by rapid industrialisation and increasing population can't be unheeded. This can directly be linked with immense amount of carbon emission and this process seems to be augmentative and ageless. Seeing vagaries in climate, an international joint action is captious in steering an effectual, impartial and economical response to this challenge. For a vast country like India which stands sixth in the world in terms of energy consumptions, the dependency on a single resource or technology to carry out all energy requirement while tackling issues related to environmental impacts and fuel supplies is impractical and undoable [1]. Therefore incorporating non-carbon emitting resources have become an integral part to attain sustainability and cut down burden on fossil fuel reserves. Seeing India's domestic market and large number of investors, country is ideally placed to take benefit from what renewable energy sources can offer. The variations in climatic zones provides ample amount of wind, sunlight, water flow rate which have enormous potential to undergo growth to energy sector and can be an alternative to fossil fuels. If given full support by the government, India can establish itself as world leader in judiciously using its resources of business and private investors for expanding renewable energy. Focusing on clean energy and seeing its enormous potential, renewable energy is likely to become

Manuscript received October 10, 2013; revised March 3, 2014.

Rijul Dhingra, Abhinav Jain, Abhishek Pandey, and Srishti Mahajan are with Delhi Technological University, Delhi, India, 110042 (e-mail: Rijuldhingra93@gmail.com, abhishekp131@gmail.com, srishtimahajan.94@gmail.com). the foundation of India's energy sector.

The key drivers for renewable energy are [2]:

1) Large unexplored potential

2) Gap between demand and supply with increase in population

3) Environmental concerns

4) Beef up India's energy security

5) Pressure from shareholders on high emission industry sectors

6) A practical solution for rural electrification

In present scenario, India is one of the largest consumers of fossil fuel such as crude oil, coal etc. This uncontrollable increase in use of Non-renewable energies such as fossil fuel, oil, natural gas has led to fluctuation of demand \& supply. This leads us to the uncertainty of the future of Nonrenewable energies. Having a negative Energy Balance for decades, India is forced to purchase energy from other countries to fulfill the needs of the entire country. The advancement of renewable energy resources will accelerate the development of the energy sector in the country so that it can meet its growth aspirations.

\section{Why Are Renewable Sources Better Than OIL RESOURCES?}

A broad comparison between renewable sources of energy and oil resources based on some factors is given below, see Table I. It indicates that renewable resources are the future for the country in the energy sector and there is a need to completely unleash the potential of these resources.

TABLE I: DIFFERENCE BETWEEN RENEWABLE ENERGY AND OIL RESOURCES

\begin{tabular}{|c|c|c|}
\hline & $\begin{array}{c}\text { Renewable sources of } \\
\text { energy }\end{array}$ & Oil Reserves \\
\hline 1. Availability & $\begin{array}{c}\text { They are abundant in } \\
\text { nature }\end{array}$ & $\begin{array}{l}\text { Oil reserves are limited } \\
\text { in nature }\end{array}$ \\
\hline $\begin{array}{c}2 . \\
\text { Regeneration }\end{array}$ & $\begin{array}{l}\text { Can be Regenerated; } \\
\text { Inexhaustible resource }\end{array}$ & $\begin{array}{c}\text { Ore is drained, can't be } \\
\text { regenerated }\end{array}$ \\
\hline 3. Emission & Zero emission & $\begin{array}{l}\text { releases greenhouse } \\
\text { gases }\end{array}$ \\
\hline $\begin{array}{l}4 . \\
\text { Environmental } \\
\text { effect of use }\end{array}$ & $\begin{array}{l}\text { There is no adverse } \\
\text { effect on } \\
\text { Environment. The whole } \\
\text { system is pollution free } \\
\text { and environment } \\
\text { friendly. }\end{array}$ & $\begin{array}{l}\text { Harmful to the } \\
\text { environment }\end{array}$ \\
\hline $\begin{array}{c}5 . \\
\text { Transportation }\end{array}$ & $\begin{array}{l}\text { Used where it is } \\
\text { available or } \\
\text { transported where } \\
\text { needed }\end{array}$ & $\begin{array}{l}\text { Has to be transported } \\
\text { from its source site for } \\
\text { further processing, } \\
\text { exposing the } \\
\text { environment to } \\
\text { pollution from accidents }\end{array}$ \\
\hline 6. Distribution & $\begin{array}{l}\text { Evenly distributed in } \\
\text { world. }\end{array}$ & $\begin{array}{l}\text { Uneven distribution } \\
\text { which leads to flow gap } \\
\text { and price fluctuations. }\end{array}$ \\
\hline
\end{tabular}




\begin{tabular}{|c|c|c|}
\hline $\begin{array}{c}7 . \\
\text { Development }\end{array}$ & $\begin{array}{c}\text { Leads to more } \\
\text { sustainable development. } \\
\text { i.e. more jobs } \\
\text { opportunities }\end{array}$ & $\begin{array}{c}\text { Lesser sustainable } \\
\text { development }\end{array}$ \\
\hline 8. Storage & $\begin{array}{l}\text { Need storage between } \\
\text { production and } \\
\text { consumption. }\end{array}$ & $\begin{array}{l}\text { Portable form of energy. } \\
\text { Easy to store }\end{array}$ \\
\hline $\begin{array}{l}\text { 9. Climate } \\
\text { Change }\end{array}$ & $\begin{array}{c}\text { Depends on altercation } \\
\text { of climate }\end{array}$ & $\begin{array}{c}\text { Do not depend on } \\
\text { weather modifications }\end{array}$ \\
\hline 10. Area & $\begin{array}{c}\text { Large amount of land is } \\
\text { required }\end{array}$ & $\begin{array}{c}\text { Not large geographical } \\
\text { area is required }\end{array}$ \\
\hline $\begin{array}{l}\text { 11. Geo- } \\
\text { political } \\
\text { implications }\end{array}$ & $\begin{array}{l}\text { Reduces our reliance on } \\
\text { oil, } \\
\text { Safe guarding national } \\
\text { security. } \\
\text { Allows for self- } \\
\text { sufficiency [3] }\end{array}$ & $\begin{array}{c}\text { Over-reliance on oil as a } \\
\text { resource can undermine } \\
\text { a country's energy } \\
\text { security. [3] }\end{array}$ \\
\hline 12. Cost & $\begin{array}{l}\text { High Capital and } \\
\text { Maintenance cost.[4] }\end{array}$ & $\begin{array}{l}\text { Cost of producing is } \\
\text { low since they are } \\
\text { naturally available. } \\
\text { Furthermore they are } \\
\text { cheap to transform from } \\
\text { one form of energy to } \\
\text { another. [4] }\end{array}$ \\
\hline $\begin{array}{l}\text { 13. Energy } \\
\text { Supply }\end{array}$ & $\begin{array}{l}\text { Once generated, they } \\
\text { produce high amount of } \\
\text { energy. }\end{array}$ & limited supply only \\
\hline
\end{tabular}

\section{RENEWABLE ENERGy SCENARIO IN INDIA}

Hydro - Falling rainfall can be a very good indicator for people to judge those areas where water can be readily available to be used to produce energy from it. This kind of energy produced from water is known as hydroelectric energy. These hydroelectric power plants can then be implemented in such regions of heavy rainfall. There are 12 major such plants in India- 3 in Bihar, 2 in Andhra Pradesh and one in Punjab, Uttaranchal, Karnataka, Uttar Pradesh, Sikkim, Jammu and Kashmir and Gujarat each.

Biomass - One third contributor of energy to India is biomass with a potential of 22,536MW - [5] which comprises of solid biomass, which is an organic, non-fossil material of biological origins. Biogas which is principally methane and carbon dioxide is produced by anaerobic digestion of biomass and combusted to produce heat. Currently, India has 3697MW [6] installed capacity. Following is a list of some States with most potential for biomass reduction: Andhra Pradesh (200 MW), Bihar (200 MW), Gujarat (200 MW), Karnataka (300 MW), Maharashtra (1,000 MW), Punjab (150 MW), Tamil Nadu (350 MW), Uttar Pradesh (1,000 MW) [7].

Solar - India being situated between the tropic of cancer and the equator, has an average temperature of $25^{\circ} \mathrm{C}-$ $27.5^{\circ} \mathrm{C}$ [7] and receives $260-300$ clear sunny days per year making it the best solar resource in the world. India has an installed power capacity of $1686 \mathrm{MW}$, making it sixth largest consumer in the world. Major plants are located in Gujarat, Rajasthan, Jodhpur, Tamil Nadu and Orissa.

Wind - Electrical energy and mechanical energy can also be produced by wind energy. India has 19051 MWof installed capacity and ranks 5th and has a potential of utilization up to $102772 \mathrm{MW}$. Some of the major wind energy plants are located in Tamil Nadu (7160MW), Gujarat (3093MW) and Maharashtra (2976MW).

Geothermal - One energy sources that has not been exploited at all, is the geothermal energy, which is an enormous, underused heat and power resource that is clean, reliable and home grown. [8]With growing dependence on coal and with increasing environmental problems, India will soon have to start exploiting this source of energy which has a potential of about 10000 MW [9]. Chhattisgarh government has decided to establish the first Geothermal Power Plant of the country in Tattapani area of the Balrampur district with the help of NTPC.

Nuclear - Nuclear power stands fourth in electricity generation in India after thermal, hydro and wind. India stands ninth in the world in terms of number of operational nuclear power reactors and has 20 nuclear reactors in operation in six nuclear power plants, generating 5,780 MW, also seven nuclear reactors are under construction. India's electricity generation is expected to reach $20,000 \mathrm{MW}$ by 2020. The Biggest Nuclear plant in India is located in Tarapur, Maharashtra, $1400 \mathrm{MW}$, followed by Rawatbhata in Kota Rajasthan, 1180 MW and KaigaKarnataka, 880 MW. Kudankulam, Tamil Nadu of 2000MW, India's biggest power plant is under construction.

Ocean - There is a huge potential of tidal and marine energy in India which can be produced from ocean. For the tidal energy potential- locations are the Gulf of Cambay and the Gulf of Kachchh on the west coast with max tidal range$8 \mathrm{~m}$ to $11 \mathrm{~m}$ and average range- $5 \mathrm{~m}$ to $7 \mathrm{~m}$. The Ganges Delta, Sunder bans West Bengal too has good locations for small scale tidal power development. The tidal power potential in India is 8000-9000 MW- 7000 MW [10] in the Gulf of Cambay, 1200 MW in the Gulf of Kachchh and less than 100 MW in Sunder bans. And for the marine energy potential- along the $6000 \mathrm{Km}$ of coast is about 40,000 MW. A British tidal energy company, Atlantis Resources, is expected to set up a tidal power plant with the capacity to generate over $50 \mathrm{MW}$ inthe Gulf of Kutch with construction already started in early 2012.

\section{Multi-Criteria Assessment of Renewable ENERGY}

An assessment of different types of renewable energies is carried out, see Table II.

TABLE II: DIFFERENCE BETWEEN WIND, HydRo, BIOMASS, SOLAR, GEOTHERMAL, OCEAN, NuCLEAR ENERGY

\begin{tabular}{|c|c|c|c|}
\hline Criteria & Wind & Hydro & Biomass \\
\hline 1. Efficiency (\%) & $30[10]$ & $80[10]$ & $1[10]$ \\
\hline 2. Land requirement & High & Very high & Extremely high \\
\hline 3. Approx. Potential For India (MW) & 102772 & 84000 & 22536 \\
\hline
\end{tabular}




\begin{tabular}{|c|c|c|c|}
\hline 4. Electricity cost (c/kWh) & 7 & 8 & 14 \\
\hline 5. Installed capacity $(\mathrm{MW})$ & 19051 & 38748 & 1.18 \\
\hline 7. Carbon dioxide $\left(\mathrm{kgCO}_{2} / \mathrm{KWh}\right)$ & 0.02 & Moderate & Low \\
\hline 6. Work qualifications & Low & High & Low \\
\hline $\begin{array}{c}\text { 8. Independence of electricity } \\
\text { generation }\end{array}$ & Very High & Very high & Low \\
\hline 9. Turnkey cost & Low & High & Moderate \\
\hline 10. Social And individual risks & Low & Very high & Nowastes \\
\hline 11. Construction time & No waste & Inexhaustible & $\begin{array}{c}\text { Developed By Keeping in mind } \\
\text { the availability of biomass }\end{array}$ \\
\hline 12. Wastes Generated & Inexhaustible & Low & Very low \\
\hline $\begin{array}{c}\text { 13. Energy Source } \\
\text { 14. Operation \& management costs }\end{array}$ & Very low & Lery High & Low \\
\hline $\begin{array}{c}\text { 15. Necessity of participative decision- } \\
\text { making processes }\end{array}$ & & & \\
\hline
\end{tabular}

\begin{tabular}{|c|c|c|c|c|}
\hline Criteria & Solar & Geothermal & Ocean & Nuclear \\
\hline 1. Efficiency (\%) & 15 & 8 & 3 & 33 \\
\hline 2. Land requirement & High & Low & Very low & Very low \\
\hline Criteria & Solar & Geothermal & Ocean & Nuclear \\
\hline $\begin{array}{l}\text { 3. Approx. Potential For } \\
\text { India (MW) }\end{array}$ & - & 10000 & 40000 & - \\
\hline 4. Electricity $\operatorname{cost}(\mathrm{c} / \mathrm{kWh})$ & 17 & 8 & 25 & 4 \\
\hline 5. Installed capacity (MW) & 1686 & 0 & 1 & 5780 \\
\hline $\begin{array}{l}\text { 7. Carbon dioxide } \\
\left(\mathrm{kgCO}_{2} / \mathrm{KWh}\right)\end{array}$ & 0.1 & 0.06 & 0.02 & 0.025 \\
\hline 6. Work qualifications & Low & Moderate & High & Very High \\
\hline $\begin{array}{l}\text { 8. Independence of } \\
\text { electricity } \\
\text { generation }\end{array}$ & Very High & High & High & Low \\
\hline 9. Turnkey cost & Low & High & High & Very high \\
\hline $\begin{array}{l}\text { 10. Social And individual } \\
\text { risks }\end{array}$ & Low & Low & Low & Very High \\
\hline 11. Construction time & Low & High & High & High \\
\hline 12. Wastes Generated & No waste & No waste & No waste & $\begin{array}{c}\text { Highly toxic } \\
\text { Wastes generated }\end{array}$ \\
\hline 13. Energy Source & Inexhaustible & $\begin{array}{l}\text { Limited sites but } \\
\text { Inexhaustible }\end{array}$ & Variable but Inexhaustible & Exhaustible \\
\hline $\begin{array}{l}\text { 14. Operation \& } \\
\text { management costs }\end{array}$ & Very low & Low & Moderate & High \\
\hline $\begin{array}{l}15 . \text { Necessity of } \\
\text { participative decision- } \\
\text { making processes }\end{array}$ & Low & Low & Low & Very high \\
\hline
\end{tabular}

\section{ANALYSIS AND FINDINGS}

The efficiency of the conversion processes involved is highest in hydro at about $80 \%$ and least for biomass and ocean.

Land requirement for biomass energy is higher in comparison to others as it needs significant amount of land for the biomass. Hydro power also require large amount of land in creating the reservoirs.

Carbon dioxide generated is only high for the biomass energy, all other renewable energy involve negligible or very low $\mathrm{CO}_{2}$ emissions.

Work qualifications consider average years of education for workforce which considers the technicality of the processes involved. It is very high for Nuclear Energy as compared to others with solar, wind requires very low work qualifications.

Turnkey cost is very high for Nuclear and Hydropower since plants or projects of these require high capital input than others. 
Social and individual risk includes subjective health fears due to normal operation as well as Health effects from accidents. In case of Nuclear energy risks involved are high as also witnessed over the time and recently in Fukushima reactor incident in Japan. Wind, solar, geothermal etc. does not involve such high risks.

Wastes generated are nearly negligible except for Nuclear power where highly radioactive wastes are produced and require proper waste management.

Autonomy of electricity generation is very high for wind, solar, biomass, etc. but is questionable in case nuclear energy because fuel sometimes comes from other countries and hydro where projects on rivers flowing through more than one nation have certain risks.

Energy source for wind, solar, geothermal and ocean are inexhaustible whereas for biomass and nuclear power, it is exhaustible.

Necessity of participative decision-making processes is pretty high in cases of nuclear and hydro power as risks for the stakeholders involved are high. It's pretty low in case of other sources.

Operation \& management costs are high for nuclear power whereas nearly all other have comparatively low O\&M costs.

\section{CONCLUSION}

Looking at the present scenario, a sustainable energy system in country like India is essential/the need of the hour for sustainable development. Because of the Inequality in energy distribution, renewable energy has the possibility of becoming the foundation for the country's future energy requirements. An analysis on the demand for new renewable technologies clearly shows a shift in preference towards these technologies as a source of energy- wind, biomass, and geothermal, tidal and marine, hydropower, solar photovoltaic. The popularity of renewable technologies can be noted by continued rapid growth, despite economic breakdown and financial crisis. Introduction and use of renewable energy on a large scale will help in tackling issues like energy scarcity, variations in fuel prices and help India to be self-sustainable. India is already facing energy crisis as many parts still survive without electricity, hence renewable energy can act as panacea to its problems. [11] But availability of capital is inhibiting the growth of renewable energy. Future growth in renewable energy will require new technology, favourable policies backed by innovative financing. This report calls upon all the stakeholders to take charge and discuss the conditions that favour renewable energy deployment and find creative solutions. The Indian government should realize the long term benefits of renewable power generation and mark it top priority during their economic growth plans. They should increase their financial support for renewable energy in a variety of ways which includes funds for demonstration projects and loan guarantees. These measures will help in shifting the similar investment schemes of energy sector away for typically undervalued investment costs of fossil fuels. This report is meant only as an overview in hopes that it will encourage even more rapid and extensive development of the renewable energy resources on the
Indian subcontinent.

\section{REFERENCES}

[1] D. S. Arora, S. Busche, S. Cowlin, T. Engelmeier, H. Jaritz, A Milbrandt, and S. Wang, "Indian renewable energy status report," NREL, October 2010.

[2] New Renewable Energy in India: Harnessing the Potential, ExportImport Bank of India, pp. 116-118, January 2011.

[3] V. Verneker, "Distributed Renewable Energy Generation in India," M.Sc. thesis, Dept. of Sustainable Energy \& Environment, Cardiff University, Cardiff, United Kingdom, Sept. 2008.

[4] S. Guru, "Renewable energy sources in India, is it viable?" Working Papers Series, Julian Simon Centre for Policy Research, October 2002.

[5] State-wise potential of various renewable energy technologies. (July 2013). [Online]. p. $1 . \quad$ Available: http://data.gov.in/sites/default/files/Statewise_Potential_of_Various_ Renewable_Energy_Technologies_1.xls

[6] Report to the people. (2013). [Online]. pp. 37-38. Available: http://pmindia.gov.in/report_to_people/20122013/report_PMO_English.pdf

[7] P. Meisen and E. Quéneudec. (October 2006). Overview of sustainable renewable energy potential of India. [Online]. Available: http://www.geni.org/globalenergy/research/renewable-energypotential-of-

india/Renewable\%20Energy\%20Potential\%20for\%20India.pdf

[8] R. K. Gera, H. M. Rai, Y. Parvej, and H. Soni, "Renewable energy scenario in India: Opportunities and challenges," Indian Journal of Electrical and Biomedical Engineering, vol. 1, no. 1, pp. 10-16, 1 January-June 2013.

[9] Delhi International Energy Conference 2010. [Online]. Available: http://www.direc2010.gov.in/geothermal.html.

[10] N. H. Afgan and M. G. Carvalho, "Multi-criteria assessment of new and renewable energy power plants," Energy, vol. 27, pp. 739-755, 2002.

[11] A. Ringwald, "India renewable energy trends," Centre for Social Markets, July 2008.

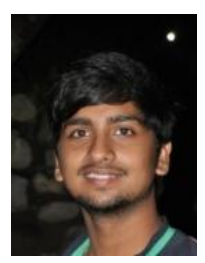

Rijul Dhingra was born on August 23, 1993 in Delhi. $\mathrm{He}$ is currently pursuing $\mathrm{B}$. Tech in environmental engineering from Delhi Technological University, Delhi.

He has completed 6 weeks internship at Central Pollution Control Board (CPCB), Delhi. A review paper on the millennium development goals is accepted at the Clute Institute, Orlando. His current interests are future development of India in the environmental industry, quality control/assurance of air, water supply.

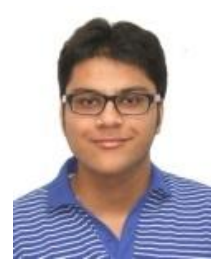

Abhinav Jain was born on September 29, 1993 in Delhi. $\mathrm{He}$ is currently pursuing B. Tech in environmental engineering from Delhi Technological University, Delhi.

He has completed 6 weeks internship at Central Pollution Control Board (CPCB), Delhi. His curren interests are renewable energy, water supply and wastewater treatment.

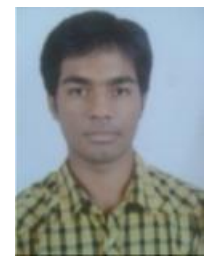

Abhishek Pandey was born on January 31, 1993 in Delhi. $\mathrm{He}$ is currently pursuing B. Tech in environmental engineering from Delhi Technological University, Delhi.

He has completed 6 weeks internship at Central Pollution Control Board (CPCB), Delhi. His current interests are noise monitoring system and renewable energy.

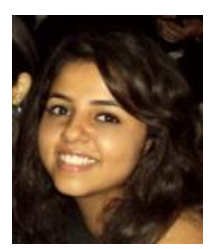

Srishti Mahajan was born on March 19, 1993 in Delhi. She is currently pursuing B. Tech in environmental engineering from Delhi Technological University, Delhi.

A review paper on the millennium development goals is accepted at the Clute Institute, Orlando. Her current interests are renewable energy and waste water treatment, remote sensing. 